\title{
Komunikasi Organisasi pada Biro Fasilitasi Kebijakan Energi dan Persidangan Sekretariat Jenderal Dewan Energi Nasional
}

\author{
Thoriq Ramadani \\ Kementerian Energi dan Sumber Daya Mineral \\ E-mail: thoriq.ramadani@esdm.go.id
}

DOI: https://doi.org/10.21107/ilkom.v14i2.7076

\begin{abstract}
ABSTRAK
Penelitian bertujuan mengetahui iklim komunikasi organisasi dan strategi komunikasi pada Biro Fasilitasi Kebijakan Energi dan Persidangan Sekretariat Jenderal Dewan Energi Nasional. Metode yang digunakan adalah paradigma kualitatif dengan metode studi kasus. Pengumpulan data primer dilakukan dengan wawancara terhadap key informants dan data sekunder dengan melakukan peninjauan literatur. Hasil penelitian mengungkapkan bahwa iklim komunikasi organisasi pada faktor pimpinan, memberikan motivasi kepada bawahan untuk menjalankan pekerjaan dengan baik. Pada faktor tingkah laku pegawai, masih terkotak-kotak antar generasi, antar Bagian, dan beberapa orang belum berkomunikasi secara dua arah dengan baik. Pada tingkah laku kelompok kerja terkotak-kotak antar Bagian. Faktor eksternal organisasi, penurunan anggaran memiliki efek terhadap produktivitas kerja. Strategi komunikasi, komunikator adalah pimpinan yang dapat mempersatukan seluruh pegawai. Target yang ditetapkan adalah seluruh pegawai. Pesan yang disusun berisi kebijakan. Media yang digunakan aplikasi WhatsApp dan e-mail. Saluran komunikasi yang digunakan kelompok melalui rapat Biro, rapat Bagian, antar pribadi seperti e-mail, telepon, WhatsApp, dan Short Message Service (SMS). Efek yang diharapkan adalah keguyuban.
\end{abstract}

Kata kunci : : Iklim Komunikasi Organisasi, Komunikasi Organisasi, Strategi Komunikasi

\section{ABSTRACT}

This study aims to determine the organizational communication climate and communication strategy at Bureau of Energy Policy Facilitation and Trial Secretariat General of the National Energy Council. The method used is a qualitative paradigm with a case study method. Primary data collection was carried out by interviewing key informants and secondary data by conducting a literature review. The research results reveal that the organizational communication climate on the leadership factor provides motivation to subordinates to do their job well. In terms of employee behavior, it is still fragmented between generations, between divisions, and some people have not communicated both ways well. The behavior of the work group is divided between divisions. External factors of the organization, decreased budget has an effect on work productivity. Communication strategy, the communicator is a leader who can unite all employees. The target set is all employees. Compiled messages contain policies. The media used by WhatsApp and e-mail applications. Communication channels used by groups are through Bureau meetings, Division meetings, interpersonal such as e-mail, telephone, WhatsApp, and Short Message Service (SMS). The expected effect is togetherness.

Keywords : Climate of Organizational Communications, Organizational Communications, Communication Strategies

\section{Cite this as :}

Ramadani, Thoriq (2020). Komunikasi Organisasi pada Biro Fasilitasi Kebijakan Energi dan Persidangan Sekretariat Jenderal Dewan Energi Nasional.Jurnal Komunikasi, 14(2), 119-134. Doi : https://doi.org/10.21107/ilkom.v14i2.7076

Article History :

Received April, $13^{\text {th }} 2020$

Acepted July, $25^{\text {th }} 2020$ 


\section{PENDAHULUAN}

Pengelolaan energi di tanah air merupakan hal yang sangat penting. Energi mempunyai posisi yang sangat strategis dalam pembangunan suatu negara, khususnya dalam mengakselerasi kemajuan ekonomi suatu negara (Santoso, 2017: 28). Energy is viewed as the most crucial sector in elements of state's power ini recent times. Energy sector is not only closely associated to the economic progress of a state but also determined the standing of a state in the committee of nations (Khalid \& Mukhtar, 2016: 101).

Energi dalam Undang-Undang (UU) Nomor 30 tahun 2007 tentang Energi adalah kemampuan untuk melakukan kerja yang dapat berupa panas, cahaya, mekanika, kimia dan elektromagnetika. Peranan energi sangat penting artinya bagi peningkatan kegiatan ekonomi dan ketahanan nasional, sehingga pengelolaan energi yang meliputi penyediaan, pemanfaatan dan pengusahaannya harus dilaksanakan secara berkeadilan, berkelanjutan, rasional, optimal dan terpadu.

Untuk itu, UU No 30 tahun 2007 memberikan amanat kepada Presiden untuk membentuk Dewan Energi Nasional (DEN). DEN bertugas:

1. Merancang dan merumuskan Kebijakan Energi Nasional (KEN) untuk ditetapkan oleh Pemerintah dengan persetujuan Dewan Perwakilan Rakyat (DPR)

2. Menetapkan Rencana Umum Energi Nasional (RUEN)

3. Menetapkan langkah-langkah penanggulangan kondisi krisis dan darurat energi

4. Mengawasi pelaksanaan kebijakan di bidang energi yang bersifat lintas sektoral.

Dalam menjalankan tugasnya DEN dibantu oleh Sekretariat Jenderal (Setjen) DEN, Biro Fasilitasi Kebijakan Energi dan Persidangan menjadi salah satu Biro di lingkungan Sekretariat Jenderal (setjen) DEN. Sesuai Peraturan Menteri (Permen) Energi dan Sumber Daya Mineral (ESDM) No. 14 Tahun 2009 tentang Tugas dan Fungsi
Organisasi menyebutkan Biro Fasilitasi Kebijakan Energi dan Persidangan memiliki tugas membantu Setjen DEN dalam penyelenggaraan persidangan, penyiapan dan pengelolaan bahan-bahan persidangan DEN dalam rangka perancangan dan perumusan KEN dan penetapan RUEN, penyelenggaraan hubungan kemasyarakatan (Humas) serta fasilitasi kegiatan Kelompok Kerja.

Biro Fasilitasi Kebijakan Energi dan Persidangan menjadi Biro yang memfasilitasi Anggota DEN dalam melaksanakan tugas yaitu (1) merancang dan merumuskan KEN untuk ditetapkan oleh Pemerintah dengan persetujuan DPR, produk hukum KEN adalah Peraturan Pemerintah (PP) No 79 Tahun 2014 tentang KEN, dan (2) menetapkan RUEN, yang produk hukumnya adalah Peraturan Presiden (Perpres) No 22 Tahun 2017 tentang RUEN. Biro Fasilitasi Kebijakan Energi dan Persidangan Setjen DEN memiliki peran yang strategis dalam memfasilitasi persidangan DEN, yaitu Sidang Anggota yang dipimpin oleh Ketua Harian DEN yaitu Menteri ESDM dan Sidang Paripurna DEN yang dipimpin oleh Ketua DEN, yaitu Presiden.

Dengan peran yang strategis tersebut, iklim komunikasi dalam organisasi dan strategi komunikasi Biro Fasilitasi Kebijakan Energi dan Persidangan harus berjalan dengan optimal, dalam melaksanakan tugas organisasi yang diemban dengan segala dinamika di dalamnya. Sehingga tugas Biro Fasilitasi Kebijakan Energi dan Persidangan untuk menopang Sekretariat Jenderal DEN dalam membantu tugas DEN menjadi maksimal. Dinamika organisasi yang selalu hidup dan berkembang selalu ditandai dengan iklim komunikasi organisasi yang baik (Purnomo, 2018: 11).

Penelitian terdahulu, yang pertama, dilakukan oleh Harivarman (2016: 518) bahwa hambatan komunikasi pasti akan selalu terjadi dalam setiap proses komunikasi dalam organisasi, tak terkecuali pada organisasi pemerintahan ketika menjalankan suatu program atau kegiatan. Hasil penelitian menunjukkan bahwa Direktorat Pelaksanaan Anggaran (PA) Kementerian Keuangan 
sebagai organisasi pemerintahan menghadapi beberapa hambatan komunikasi internal dalam pelaksanaan Program Monitoring dan Evaluasi Pelaksanaan Anggaran, yaitu adanya perbedaan persepsi antara pimpinan dan bawahan terhadap pelaksanaan kegiatan dan program yang termasuk dalam perceptual distortion, terbatasnya praktik sharing informasi dari pihak manajemen kepada pegawai pelaksana dan pengarauh gaya kepemimpinan atasan dalam pelaksanaan kegiatan yang disebabkan adanya status effect dan cultural differences dalam organisasi Direktorat PA.

Dalam rangka memperoleh komunikasi yang efektif untuk kelancaran pelaksanaan program dan kegiatan di masa yang akan datang, Direktorat PA Kementerian Keuangan perlu menerapkan beberapa strategi komunikasi untuk meminimalisir hambatanhambatan yang dihadapi tersebut, Pimpinan dan pejabat Direktorat PA di tingkat manajerial perlu lebih aktif dalam menanamkan gagasan khususnya di level staf atau pelaksana, kemudian organisasi perlu menciptakan mekanisme berbagi informasi dan pengetahuan (information and knowledge sharing culture) sampai ke level staf atau pelaksana (Harivarman, 2016: 518-519).

Penelitian kedua yang dilakukan oleh Hambali; dkk, (2018: 107) pada Program Studi Ilmu Komunikasi Fakultas Ilmu Sosial Ilmu Politik Universitas Islam Negeri Raden Fatah Pelembang telah berjalan sesuai dengan sistem yang berlaku, karena alur komunikasi secara formal dalam organisasi tertata secara teratur dan mengikuti prosedur yang telah berlaku. Pola komunikasi yang dalam penyebaran informasi juga terjalin secara langsung dengan adanya feedback dari setiap penerima pesan. Selain itu dari pola komunikasi yang terbentuk, akan membuat hubungan interaksi antar anggota akan tetap harmonis karena penyebaran informasi terjadi secara transparan dan tidak kaku (Hambali; dkk, 2018: 107).

Penelitian ketiga, dilakukan oleh Purnomo (2018) mengungkapkan bahwa penerapan komunikasi organisasi yang diterapkan pada pemerintahan di Indonesia telah dikomunikasikan oleh Kepala Dinas beserta jajaran unit kerja dan bawahannya dalam menjalankan tugas pokok dan fungsi dalam membantu tugas kepemimpinan Gubernur. Pelaksanaan kebijakan komunikasi organisasi pada Pemerintahan di Indonesia tidak terlepas dari faktor-faktor yang menunjang dan menghambat. Faktor tersebut adalah faktor pimpinan, tingkahlaku sumber daya, kelompok kerja dan eksternal organisasi (Purnomo, 2018: 24).

Penelitian keempat yang dilakukan (Ramadani, 2019b) tentang pengelolaan komunikasi publik di Setjen DEN menjelaskan bahwa implementasi pengelolaan komunikasi publik di Setjen DEN sudah berjalan, walaupun masih bisa ditingkatkan. Keterbatasan anggaran dan peralatan yang ada tidak mempengaruhi motivasi bekerja dan bahkan menjadi masukkan untuk lebih meningkatkan lagi dalam hal sinergi pengelolaan komunikasi publik ke depan, melalui kerjasama dengan Kementerian/Lembaga Anggota DEN. Peningkatan pengikut media sosial yang signifikan juga menjadi salah satu ukuran pencapaian (Ramadani, 2019a: 11).

Penelitian kelima, dilakukan Pricahyadi \& Ramadani (2019: 112) pada Dinas Kependudukan dan Catatan Sipil (Disdukcapil) Pemerintah Provinsi (Pemprov) Daerah Khusus Ibukota (DKI) Jakarta dalam upaya mengkomunikasikan kebijakan Peraturan Gubernur (Pergub) Nomor 110 Tahun 2018 tentang Peningkatan Kualitas Layanan Administrasi Kependudukan. Hasil penelitian menemukan bahwa strategi komunikasi yang telah dilakukan Disdukcapil Pemprov DKI Jakarta sudah dilakukan, namun belum dijalankan dengan perencanaan yang sistematis. Bahkan, ada kekhawatiran jika masayarakat mengetahui isi Pergub tersebut, masyarakat akan menuntut pelayanan yang semakin prima, sedangkan masih adanya beberapa kendala di lapangan (Pricahyadi \& Ramadani, 2019: 112).

$$
\text { Perbedaan penelitian iklim }
$$
komunikasi organisasi dan strategi 
komunikasi di Biro Fasilitasi Kebijakan Energi dan Persidangan Setjen DEN adalah pada penelitian ini tidak hanya menggunakan prinsip yang memberikan efek pada iklim komunikasi dalam organisasi, yaitu pimpinan, tingkah laku pegawai, tingkah laku kelompok kerja, dan faktor eksternal organisasi. Penelitian ini sekaligus mengupas strategi komunikasi untuk menyebarluaskan kebijakan yaitu penetapan komunikator, penetapan target, menyusun pesan-pesan, pemilihan media dan saluran komunikasi, dan efek yang diharapkan.

Berdasarkan penjelasan di atas, penelitian bertujuan untuk mengetahui bagaimana iklim komunikasi organisasi dan strategi komunikasi di di Biro Fasilitasi Kebijakan Energi dan Persidangan Setjen DEN. Manfaat dari penelitian ini adalah menambah khazanah penelitian mengenai iklim komunikasi organisasi dan strategi komunikasi yang sudah ada, serta sebagai bahan evaluasi dan masukkan terkait iklim komunikasi dalam organisasi dan strategi komunikasi di di Biro Fasilitasi Kebijakan Energi dan Persidangan Setjen DEN.

\section{Komunikasi Organisasi}

$\begin{array}{ccr}\text { Komunikasi organisasi } & \text { adalah } \\ \text { bagaimana organisasi mewakili, }\end{array}$ menghadirkan, dan membentuk iklim dan budaya organisasi mereka-sikap, nilai, dan tujuan yang menjadi ciri organisasi dan anggotanya (Atmaja \& Dewi, 2018: 197). Komunikasi organisasi yaitu proses mengolah sistem ke dalam bentuk pesan yang sudah terencana sebelumnya yang tujuannya adalah untuk menciptakan dan saling menukar pesan di dalam sebuah organisasi formal maupun non formal untuk mengatasi lingkungan yang tidak pasti atau selalu berubah-ubah dalam rangka mencapai visi, misi dan tujuan (Hambali; dkk, 2018: 98-99).

Komunikasi organisasi terjadi dalam suatu sistem terbuka yang kompleks yang dipengaruhi oleh lingkungannya sendiri baik internal maupun eksternal yang meliputi pesan dan arusnya, tujuan, arah dan media, orang dan sikapnya, perasaannya, huubngannya dan keterampilan/ skillnya (Badrudin et al., 2017: 83). Goldhaber (1993: 6) menjelaskan mengenai komunikasi organisasi adalah, communication is essential to an organization. Information is vital to effective communication. Person who control information control power (Sugiarto et al., 2018: 1).

Alvanco (2014: 136) menyatakan komunikasi organisasi sebagai kumpulan sekelompok orang yang memiliki tujuan bersama, dalam rangka mencapai tujuan bersama tersebut faktor komunikasi menjadi faktor yang sangat penting (Jumrad \& Sari, 2019: 106). Joseph (2011: 340) menyampaikan komunikasi organisasi merupakan pengiriman dan penerimaan berbagai pesan di dalam organisasi dalam kelompok formal maupun informal organisasi, jika organisasi semakin besar dan kompleks, maka demikian juga komunikasinya (Hasyim, 2016: 9). Komunikasi internal dalam dimensi komunikasi organisasi adalah proses komunikasi yang terjadi antara angota dalam organisasi, untuk kelancaran pelaksanaan kegiatan organisasi (Harivarman, 2016: 509510).

\section{Iklim Komunikasi dalam Organisasi}

Pace dan Faules (2000: 167) menjelaskan iklim komunikasi organisasi merupakan gabungan dari persepsi-persepsi suatu evaluasi makro mengenai peristiwa komunikasi, perilaku manusia, respons karyawan terhadap karyawan lainnya, harapan-harapan, konflik-konflik antarpersona, dan kesempatan bagi pertumbuhan organisasi tersebut (A. Santoso, 2015: 2). Menurut Redding (1972) bahwa iklim (komunikasi) organisasi jauh lebih pentiing daripada keterampian/teknik komunikasi serba nyata dalam menciptakan organisasi efektif. Iklim komunikasi penting karena mengaitkan konteks organisasi 
dengan konsep, perasaan dan harapan anggota organisasi dan membantu menjelaskan periaku anggota organisasi dengan mengetahui sesuatu tentang iklim organisasi, kita dapat memahami lebih baik apa yang mendorong anggota organisasi untuk bersikap dengan cara tertentu. (Sedarmayanti, 2018: 134).

Iklim komunikasi organisasai yang baik adalah adanya rasa kepercayaan atau kejujuran dalam proses komunikasinya, selain itu ada juga pembuatan keputusan yang dilakukan secara bersama-sama, bukan secara sepihak baik itu atasan ataupun antar karyawan (A. Santoso, 2015: 1). Iklim komunikasi organisasi ini dipilih karena memiliki peranan yang penting dalam suatu organisasi Guzley (1992) dalam (Sugiarto et al., 2018: 2).

Iklim komunikasi yang baik akan dapat menimbulkan kepuasan komunikasi organisasi yaitu semua tingkat kepuasan seorang karyawan mempersepsi lingkungan komunikasi secara keseluruhan (Wijaya, 2013: 122). Iklim memiiki sifat yang membuat tampak tumpang tindih dengan konsep budaya. Budaya komunikasi dalam konteks komunikasi organisasi harus dilihat dari berbagai sisi. Sisi pertama adalah komunikasi antara atasan dan kepada bawahan. Sisi kedua antara pegawai yang satu dengan pegawai yang lain. Sisi ketiga adalah antara pegawai dan atasan (Badrudin et al., 2017: 83). Diperlukan kerjasama kedua pihak agar memiliki komunikasi dua arah atau timbal balik yang efektif.

Komunikasi antara atasan dan bawahan maupun antar karyawan yang efektif dapat membantu menentukan iklim dan semangat kerja sehingga diharapkan mampu memberikan pencerahan dan kemudahan dalam mengelola sebuah organisasi (Suparna, R, \& Winoto, 2013: 158). Menurut Higgins (1994) dalam (Sedarmayanti, 2018: 131-132), ada empat prinsip yang mempengaruhi iklim organisasi, yaitu:
1. Pimpinan

Setiap keputusan pimpinan mempengaruhi iklim organisasi dalam beberapa hal, seperti aturan, kebijakan dan prosedur organisasi terutama masalah yang berhubungan dengan masalah personalia, distribusi imbalan, gaya komunikasi, cara-cara yang digunakan untuk memotivasi, teknik dantindakan pendisiplinan, interaksi antar pimpinan dan kelompok, interaksi antar kelompok, perhatian pada permasalahan yang dimiliki pegawai dari waktu ke waktu, serta kebutuhan akan kepuasan dan kesejahteraan pegawai.

2. Tingkah laku pegawai

Tingkah laku pegawai mempengaruhi iklim melalui kepribadian mereka, terutama kebutuhan mereka dan tindakan yang mereka lakukan untuk memuaskan kebutuhan tersebut. Komunikasi karyawan memainkan bagian penting dalam membentuk iklim. Cara seseorang berkomunikasi menentukan tingkat sukses atau gagalnya hubungan antar manusia.

3. Tingkah laku kelompok kerja

Kelompok berkembang dalam organisasi dengan dua cara, yaitu secara formal, utamanya pada kelompok kerja dan informal sebagai kelompok persahabatan atau kesamaan minat.

4. Faktor eksternal organisasi

Sejumlah faktor eksternal organisasi memengaruhi iklim pada organisasi tersebut. Keadaan ekonomi adalah faktor utama yang mempengaruhi iklim.

\section{Strategi Komunikasi}

Strategi komunikasi merupakan penentu berhasil tidaknya kegiatan komuniasi secara efektif (Rodiah \& Yusup, 2018: 4). Strategi komunikasi menurut Uchjana (1993) merupakan suatu kemampuan manajemen 
dalam mencapai tujuan (Erliana, 2005: 44). Rogers (1982) memberi batasan pengertian strategi komunikasi sebagai suatu rancangan yang dibuat untuk mengubah tingkah laku manusia dalam skala lebih besar melalui transfer ide-ide baru (Cangara, 2018: 64).

$\begin{array}{lrr}\text { Strategi komunikasi merupakan } \\ \text { panduan perencanaan } & \text { komunikasi } \\ \text { (communication planning) } & \text { dengan }\end{array}$
manajemen komunikasi (communication management) untuk mencapai tujuan yang telah ditetapkan. (Rosfiantika \& Rodiah, 2015: 275). Middleton (1980) menyatakan definisi strategi komunikasi adalah kombinasi yang terbaik dari semua elemen komunikasi mulai dari komunikatro, pesan, saluran (media), penerima sampai pada efek yang dirancang untuk mencapai tujuan komunikasi yang optimal (Cangara, 2018: 64).

Diseminasi komunikasi publik terhadap Nawa Cita, Government Public Relation bertujuan untuk memberikan kesadaran pemerintah untuk berkomunikasi dengan masyarakat, menciptakan komunikasi dua arah untuk mendapatkan input dari masyarakat dan meningkatkan kapasitas komunikasi pemerintah (Ramadani, 2019b: 5) Persoalan yang timbul adalah konsep diseminasi komunikasi publik merupakan salah satu strategi komunikasi. Dalam menetapkan strategi komunikasi ada beberapa tahapan antara lain penetapan komunikator, penetapan target, menyusun pesan-pesan, pemilihan media dan saluran komunikasi, dan efek yang diharapkan. tidak berhasil dengan baik, maka kesalahan utama bersumber dari komunikator. Sebagai pelaku utama dalam aktivitas komunikasi, komunikator memegang peranan sangat penting. Cangara (2018: 133) menyampaikan ada tiga syarat utama yang harus dipenuhi oleh seorang komunikator, yaitu :

1. Tingkat kepercayaan orang lain terhadap dirinya (kredibilitas),

2. Daya tarik (attractive), dan

3. Kekuatan (power)
Kedua, Penetapan Target. Dalam dunia bisnis masayrakat diistilahkan dengan sebutan pasar, dalam studi komunikasi disebut khalayak (audience), sementara dalam dunia politik disebut publik. Memahami masyarakat terutama yang akan menjadi target merupakan hal yang sangat penting. Di dalam masyarakat ada kelompokkelompok yang menentukan pengaruh. Kelompok itu adalah (1) kelompok yang memberi izin, yaitu suatu lembaga atau badan-badan yang membuat peraturan dan memberi izin sebelum suatu program disebarluaskan. (2) Kelompok pendukung, kelompok yang mendukung dan setuju pada program yang akan dilaksanakan, (3) kelompok oposisi, mereka yang menentang atau bertentangan dengan ide perubahan yang ingin dilakukan, dan (4) kelompok evaluasi, mereka yang terdiri dari orang-orang yang mengkritisi dan memonitor jalannya suatu program, misalnya unsur legislatif yang terus memantau pelaksanaan program, sejauh mana manfaat dan efeknya terhadap masyarakat (Cangara, 2018: 136-137).

Ketiga, menyusun Pesan. Ada tiga teori yang membicarakan tentang penyusunan pesan, yaitu (1) over power 'em theory, teori ini menunjukkan bahwa bila pesan seringkali diulang, panjang dan cukup keras, maka pesan itu akan berlalu dari khalayak. (2) Glamour theory, suatu pesan (ide) yang dikemas dengan cantik, kemudian ditawarkan dengan daya persuasi, maka khalayak akan tertarik untuk memiliki ide itu, dan (3) dont tell'em theory, bila suatu ide tidak disampaikan kepada orang lain, maka mereka tidak akan memegangnya dan menanyakannya, karena itu mereka tidak akan membuat pendapat tentang ide itu (Cangara, 2018: 140).

Keempat, pemilihan media dan saluran komunikasi. Memilih media komunikasi harus mempertimbangkan karakterisik isi dan tujuan pesan yang ingin disampaikan dan jenis media yang dimiliki khalayak (Cangara, 2018: 146). Media komunikasi terdiri dari media cetak seperti 
surat kabar, majalah dan tabloid, media elektronik seperti televisi dan radio, media luar ruang seperti spanduk, umbul-umbul, media daring seperti situs berita internet dan media sosial seperti Instagram, Facebook dan Twitter serta WhatsApp, selain itu ada juga aplikasi internal Nota Dinas Elektronik (Nadine).

Sementara itu, saluran komunikasi terdiri dari (1) saluran komunikasi kelompok, seperti kelompok partai kelompok sosial atau kelompok profesi. (2) Saluran komunikasi publik, seperti komunitas tertentu seperti agama atau partai yang sama. (3) Saluran komunikasi antar pribadi, seperti surat menyurat, telepon, simple message services (SMS), anggota keluarga, tetangga dekat, sahabat dan teman kantor, dan (4) saluran komunikasi tradisional, seperti pesta adat, upacara kelahiran, upacara kematian (berkabung), upacara perkawinaan, pesta panen, upcara perdamaian (Cangara, 2018: 149).

Kelima, efek yang diharapkan. Strategi komunikasi yang dilakukan bertujuan mempengaruhi masyarakat. Pengaruh bisa terjadi dalam bentuk (1) pengetahuan (knowledge), (2) sikap (attitude) dan (3) perilaku (behaviour). Pada tingkat pengetahuan pengaruh bisa terjadi dalam perubahan persepsi dan perubahan pendapat (opinion). Adapun yang dimaksud dengan perubahan sikap, ialah adanya perubahan internal pada diri seseorang yang diorganisasi dalam bentuk prinsip, sebagai hasil dari evaluasi yang dilakukannya terhadap suatu obyek. Sementara yang dimaksud dengan perubahan perilaku ialah perubahan yang terjadi dalam bentuk tindakan (Cangara, 2018: 165)

\section{METODE PENELITIAN}

Penelitian menggunakan paradigma kualitatif dengan metode studi kasus di di Biro Fasilitasi Kebijakan Energi dan Persidangan Setjen DEN. Data terdiri dari data primer dan data sekunder. Pengumpulan data primer dilakukan dengan wawancara terhadap key informants. Data sekunder dengan melakukan peninjauan literatur, seperti jurnal, buku dan peraturan terkait. Penelitian menggunakan analisis prinsip yang mempengaruhi iklim organisasi yang disampaikan Higgins (1994) dan strategi komunikasi yang disampaikan Cangara (2018).

Selanjutnya, analisis data dengan cara, yaitu pertama, pengumpulan data untuk memperolah informasi berupa kalimatkalimat yang dikumpulkan melalui wawancara, observasi dan tinjauan literatur. Kedua, mereduksi data, dengan merangkum, memilah dan memfokuskan pada hal yang sesuai dengan bahasan dan mencari tema yang tepat untuk gambaran yang lebih jelas.

Ketiga, menyajikan data dengan mengorganisasi data dan menyusun pola yang berhubungan sehingga lebih mudah dipahami. Keempat, penarikan kesimpulan. Untuk menarik kesimpulan dari data yang ada melalui pola keteraturan pada iklim komunikasi organisasi dan strategi komunikasi di di Biro Fasilitasi Kebijakan Energi dan Persidangan Setjen DEN.

Pemilihan key informants berdasarkan jabatan di lingkungan Biro Fasilitasi Kebijakan Energi dan Persidangan Setjen DEN, baik itu Pimpinan Tinggi Pratama Kepala Biro, Pejabat Administrator Kepala Bagian, Pejabat Pengawas Kepala Sub Bagian maupun Pejabat Pelaksana. Key informants dimaksud yaitu Kepala Biro Fasilitasi Kebijakan Energi dan Persidangan, Kepala Sub Bagian Fasilitasi Kebijakan Penyediaan Energi, Kepala Sub Bagian Keprotokolan, Kepala Sub Bagian Dokumentasi, Pengadministrasi Data dan Protokol yang diwawancarai pada tanggal 30 Oktober 2019, Kepala Bagian Fasilitasi Rencana Umum Energi yang diwawancarai pada tanggal 1 November 2019, dan Kepala Sub Bagian Humas pada tanggal 10 November 2019. 
di bawah ini:

Berikut daftar key informants seperti

TABEL 1.

DAFTAR KEY INFORMANTS

\begin{tabular}{lll}
\hline $\mathbf{N}$ & \multicolumn{1}{c}{ Key } & \multicolumn{2}{c}{ Tugas } \\
o. & \multicolumn{1}{c}{ Informants } & \multicolumn{2}{c}{} \\
\hline 1. & Kepala Biro & Membantu Sekretaris Jenderal \\
& Fasilitasi & DEN dalam penyelenggaraan \\
& Kebijakan & persidangan, penyiapan dan \\
& Energi dan & pengelolaan bahan-bahan \\
& Persidangan & persidangan DEN dalam rangka \\
& & perancangan dan perumusan \\
& & KEN dan penetapan RUEN, \\
& & penyelenggaraan Humas
\end{tabular}

2. Kepala Melaksanakan penyiapan bahan Bagian perencanaan energi untuk Fasilitasi fasilitasi penyelenggaraan Rencana persidangan DEN

Umum

Energi

3. Kepala Sub Melakukan penyiapan bahan, Bagian data dan penelaahan, serta Fasilitasi evaluasi pelaksanaan atas Kebijakan penyiapan perumusan kebijakan Penyediaan energi di sisi penyediaan energi

Energi

4. Kepala Sub Melakukan penyusunan bahan, Bagian data dan penelaahan, serta Keprotokolan evaluasi pelaksanaan atas penyelenggaraan keprotokolan yang meliputi penyiapan jadwal, agenda, undangan dan penyelenggaraan persidangan DEN

5. Kepala Sub Melakukan penyusunan bahan, Bagian data dan penelaahan, serta Dokumentasi evaluasi pelaksanaan atas dokumentasi persidangan dan penyusunan notulen persidangan DEN

6. Kepala Sub Melakukan pengumpulan bahan Bagian dan data, pelaksanaan, serta Humas evaluasi pelaksanaan atas penyelenggaraan komunikasi kemasyarakatan, siaran dan konferensi pers, publikasi dan hubungan kelembagaan kegiatan DEN

7. Pengadminis Membantu penyusunan bahan, trasi Data data dan penelaahan, serta evaluasi pelaksanaan dokumentasi persidangan DEN
8. Protokol

Membantu penyusunan bahan, data dan penelaahan, serta evaluasi pelaksanaan atas penyelenggaraan keprotokolan persidangan DEN

Sumber: Diolah dari Permen ESDM Nomor 14 Tahun 2009 tentang Tugas dan Fungsi Organisasi Setjen DEN

\section{HASIL DAN PEMBAHASAN}

Biro Fasilitasi Kebijakan Energi dan Persidangan Setjen DEN menyelenggarakan fungsi (1) koordinasi persidangan DEN, (2) pengelolaan fasilitasi kegiatan Kelompok Kerja, (3) pengelolaan kajian kebijakan dan perencanaan energi, (4) penyusunan bahan persidangan untuk perumusan KEN, (5) penyusunan bahan persidangan untuk penelaahan atas rumusan RUEN yang disiapkan oleh Pemerintah, serta perencanaan energi daerah, (6) penyelenggaraan persidangan dan penyusunan notulen persidangan DEN, (7) penyelenggaraan keprotokolan dan kehumasan DEN dan (8) evaluasi dan pelaporan fasilitasi persidangan untuk penyusunan bahan perumusan KEN dan penetapan Rencana Umum Energi.

Biro Fasilitasi Fasilitasi Kebijakan Energi dan Persidangan Setjen DEN terdiri dari tiga bagian dan satu kelompok jabatan, yaitu (1) Bagian Fasilitasi Kebijakan Energi, (2) Bagian Fasilitasi Rencana Umum Energi, (3) Bagian Humas dan Persidangan (4) Kelompok Jabatan Fungsional.

Bagian Fasilitasi Kebijakan Energi mempunyai tugas melaksanakan penyiapan bahan persidangan kebijakan energi untuk fasilitasi penyelenggaraan persidangan DEN dan kegiatan Kelompok Kerja. Dalam melaksanakan tugas sebagaimana dimaksud, bagian Fasilitasi Kebijakan Energi menyelenggarakan fungsi (1) penyiapan koordinasi untuk penyusunan bahan persidangan kebijakan energi, (2) pelaksanaan kajian untuk perancangan kebijakan energi, (3) penyiapan bahan untuk perancangan kebijakan energi dalam persidangan DEN dan kegiatan Kelompok kerja, dan (5) evaluasi dan pelaporan pelaksanaan penyiapan bahan persidangan kebijakan energi untuk fasilitasi penyelenggaraan persidangan DEN dan kegiatan kelompok kerja.

Bagian Fasilitasi Rencana Umum Energi mempunyai tugas melaksanakan 
penyiapan bahan perencaan energi untuk fasilitasi penyelenggaraan persidangan DEN dan kegiatan Kelompok Kerja. Dalam melaksanakan tugas sebagaimana dimaksud, Bagian Fasilitasi Rencana Umum Energi menyelenggarakan fungsi (1) penyiapan koordinasi untuk penyusunan bahan persidangan perencanaan energi, (2) pelaksanaan kajian perencanaan energi nasional dan daerah, (3) penyiapan bahan penyusunan rancangan RUEN, (4) penyiapan bahan untuk penelaahan neraca energi, dan (5) evaluasi dan pelaporan pelaksanaan penyiapan bahan perencanaan energi untuk fasilitasi penyelenggaraan persidangan Dewan Energi Nasional dan kegiatan Kelompok Kerja.

Bagian Humas dan Persidangan memiliki tugas melaksanakan urusan humas, keprotokolan, dan persidangan DEN, serta kegiatan Kelompok Kerja. Dalam melaksanakan tugas sebagaimana dimaksud, Bagian Humas dan Persidangan menyelenggarakan fungsi (1) penyiapan koordinasi penyelenggaraan humas dan persidangan, (2) pelaksanaan keprotokolan Sidang Paripurna dan Sidang Anggota DEN, serta kegiatan Kelompok Kerja, (3) pelaksanaan fasilitasi Sidang Paripurna dan Sidang Anggota DEN, serta kegiatan Kelompok Kerja, (4) pelaksanaan humas dan hubungan kelembagaan, (5) pelaksanaan dokumentasi dan pengumpulan bahan persidangan DEN, serta kegiatan Kelompok Kerja, (6) Penyusunan notulen persidangan DEN, dan (7) evaluasi dan pelaporan pelaksanaan humas keprotokolan, dan persidangan DEN, serta kegiatan Kelompok Kerja.

Biro Fasilitasi Kebijakan Energi dan Persidangan memiliki jumlah pegawai sebanyak dua puluh sembilan orang, dengan paling banyak menduduki Golongan/Ruang III/b yaitu sepuluh orang. Setelah itu Golongan/Ruang III/d sebanyak enam orang, Golongan/Ruang III/c sebanyak lima orang, Golongan/Ruang IV/b, III/a, dan II/d masingmasing sebanyak dua orang, serta
Golongan/Ruang IV/c dan IV/a masingmasing sebanyak satu orang.

TABEL 2.

\section{GOLONGAN/ RUANG PEGAWAI DI BIRO \\ FASILITASI KEBIJAKAN ENERGI DAN PERSIDANGAN SETJEN DEN}

\begin{tabular}{|c|c|c|}
\hline No. & Golongan/Ruang & Jumlah \\
\hline 1. & $\mathrm{II} / \mathrm{d}$ & 2 orang \\
\hline 2. & $\mathrm{III} / \mathrm{a}$ & 2 orang \\
\hline 3. & $\mathrm{III} / \mathrm{b}$ & 10 orang \\
\hline 4. & $\mathrm{III} / \mathrm{c}$ & 5 orang \\
\hline 5. & $\mathrm{III} / \mathrm{d}$ & 6 orang \\
\hline 6. & $\mathrm{IV} / \mathrm{a}$ & 1 orang \\
\hline 7. & $\mathrm{IV} / \mathrm{b}$ & 2 orang \\
\hline 8. & $\mathrm{IV} / \mathrm{c}$ & 1 orang \\
\hline $\mathrm{Tc}$ & & 29 orang \\
\hline
\end{tabular}

Sumber: Diolah dari Data Kepegawaian per 1 Oktober 2019

Iklim Komunikasi Organisasi di Biro Fasilitasi Kebijakan Energi dan Persidangan dapat dijelaskan seperti di bawah ini. Pertama, pimpinan dalam hal ini adalah Pimpinan Tinggi Pratama Kepala Biro, Pejabat Administrator Kepala Bagian, Pejabat Pengawas Kepala Sub Bagian di lingkungan Biro Fasilitasi Kebijakan Energi dan Persidangan. Menurut Kepala Bagian Fasilitasi Rencana Umum Energi:

"Karo (Kepala Biro) memberikan perintah (di Grup WhatsApp), singkat, sangat minimalis, (sehingga perlu) klarifikasi. Memberikan motivasi dari sisi yang berbeda. Kita tidak terpikirkan ada gambaran, ide baru. Bagus, kreatif, dan ingin maju bikin saja. Cukup mendorong, kreatif. (Sedangkan) masih belum jalan, reward belum (jalan).

Kepala Sub Bagian Penyediaan Energi menjelaskan:

"Sepertinya (Kepala Biro) lebih persuasif, meeting bareng. (Untuk) reward masih kurang (dijalankan), punishment (sudah) jalan karena sistem jalan seperti itu. Gaya komunikasi lebih merangkul, ketika keluar kita adalah Biro II (Biro Fasilitasi Kebijakan Energi dan Persidangan) secara utuh." 
Kepala Sub Bagian Dokumentasi, Kepala Sub Bagian Humas, Protokol dan Pengadministrasi Data menyampaikan bahwa tidak berjalannya reward di Biro Fasilitasi Kebijakan Energi dan Persidangan. Sementara itu, Kepala Sub Bagian Keprotokolan menyampaikan bahwa Kepala Biro Fasilitasi Kebijakan Energi dan Persidangan memotivasi pegawai di bawahnya.

"Berusaha men-trigger kita. Yuk, kita bikin input apa, walaupun kondisi kita saat ini. Ada willingness."

Ia menambahkan bahwa cara dirinya memberikan motivasi kepada pegawai di bawahnya adalah dengan menjelaskan mengenai dedikasi sebagai Apratur Sipil Negara (ASN):

"Once, kita sudah menentukan pilihan kita menjadi PNS (Pegawai Negeri Sipil), artinya, itu sudah jalan kita. Walaupun, kadang-kadang semangat itu didukung dengan adanya pendapatan dan pemasukkan. Kembali lagi, ada atau tidak ada tambahan, tetap kita digaji negara. Mencoba untuk membangun, yuk kita ini memang mendedikasikan diri menjadi ASN. Tunjukkan itu kita ada beban moral. Kalau tidak mau di sini, keluar."

Kedua, Tingkah Laku Pegawai. Kepala Biro Fasilitasi Kebijakan Energi dan Persidangan menyampaikan:

"Ini kita masih terkotak-kotak, per Bagian. Ini tidak campur. Milenial dan non milenial. Generasi sebenarnya, bukan masalah pekerjaan/ jabatan. Ini yang harus semua juga bisa menyadari dulu bahwa kita beda generasi, the way how to-nya berbeda. Kedua, per Bagian beda-beda (tugas dan fugsi). Kegiatan saling mengetahui, kalau tidak secara dalam, paling tidak mengetahui, tugas fungsi seperti apa. Apakah diimplementasikan, belum tentu. Kita pro aktif, karena pekerjaan harus pro aktif, kalau jaman sekarang."

Kepala Bagian Fasilitasi Rencana Umum Energi menyampaikan komunikasi sudah berjalan dengan baik, hanya saja ada beberapa orang yang cara berkomunikasinya tidak berjalan secara dua arah, jelasnya:

"Harusnya demokrasi. Ada satu-dua orang yang mendominasi. Kalau saya, lebih baik menghindar. Kalau (orang seperti itu) dihadapi, (berpotensi) menimbulkan polemik, lebih baik polemik itu ditinggalkan. (Lebih baik) kita berkomunikasi dengan orang lain yang sejalan, (agar) lebih produktif."

Lain halnya apa yang disampaikan oleh Kepala Sub Bagian Humas, menurutnya tidak hanya dalam satu Biro, bahkan ada Pelaksana yang masih berjalan sendirisendiri. Berjalan sendiri-sendiri yang dimaksud adalah belum menjalankan komunikassi organisasi secara maksimal.

Sejalan dengan itu, Kepala Sub Bagian Keprotokolan menjeaskan hal itu normatif dan wajar:
"Manusiawi, ada yang berkerja berdasarkan tanggung jawab, ada yang berkerja berdasarakan uang, saja. (Saya berharap) Biro II (Biro Fasilitasi Kebijakan Energi dan Persidangan) lebih kekeluargaan."

Kepala Sub Bagian Penyediaan Energi, Protokol dan Pengadministrasi data menjelaskan untuk menekankan pentingnya koordinasi. Lebih lanjut Kepala Sub Bagian Penyediaan Energi:

"Misalnya kita terkait kebutuhan
(organisasi), (bisa) berkoordinasi
dengan bidang lain, (untuk) menyiapkan
bahan. Paling kita berkoordinasi, mana
yang dipakai. Tidak masalah, tidak
merasa ada gap (antar pergawai).

Ketiga, Tingkah Laku Kelompok Kerja. Kepala Biro Fasilitasi Kebijakan Energi dan Persidangan menyampaikan:

"Semua (antar Bagian masih) terkotakkotak. (Walaupun) ada plus-minus, dalam perkerjaan tidak boleh terkotakkotak. Tatkala menyelesaikan perkerjaan tidak ada yang terkotak- 
kotak, solid dan solved. Saling melihat kiri-kanan. (Jangan) seperti kacamata kuda. Hal yang seperti itu kita buang, kita harus satu tim."

Kepala Sub Bagian Keprotokolan menambahkan mengenai tingkah laku kelompok secara formal di Biro Fasilitasi Kebijakan Energi dan Persidangan:
"Secara formal, masih belum maksimal. Secara formal, (masih) terkotak-kotak. Bagian Humas dan Persidangan sendiri kerjanya. Bagian Fasilitasi Rencana Umum Energi sendiri kerjanya. Bagian Fasilitasi Kebijakan Energi sendiri kerjanya. Tidak saling guyub. (Seharusnya bisa dibangun kekompakkan) apa yang bisa kita support dari sini, apa yang bisa kita support dari sana."

Kepala Bagian Fasilitasi Rencana Umum Energi menjelaskan hal berbeda:

"Bagian Fasilitasi Kebijakan Energi sudah berjalan baik (tingah laku kelompok), komunikasi sudah tektok (dua arah). Kalau tidak ada yang tahu, (yang lain) memberi tahu. Kalau berdasarkan pemintan (informal), itu lebih jalan, (seperti) hobi."

Kepala Sub Bagian Keprotokolan memandang tingkah laku kelompok secara informal sudah berjalan baik:

"(Untuk yang) perempuan kadang makan siang bareng. Laki-laki futsal bareng. (Walaupun) ada yang tidak kompak, satu-dua (orang)."

Pengadministrasi Data menyampaikan di salah satu Bagian di lingkungan Biro Fasilitasi Kebijakan Energi dan Persidangan belum terbangun kekompakkan dalam tim:
"Masih ada selisih paham. Tidak berbaur (antar anggota Bagian). (Upaya untuk membuat kompak salah satunya adalah) sering jalan bareng."

Kepala Sub Bagian Penyediaan Energi menjelaskan bahwa untuk mendorong motivasi antar anggota Bagian perlu memberikan reward:

"Harus mendorong mereka supaya lebih baik lagi (dalam bekerja). Harus didorong, dikasih motivasi, termasuk reward."

Kepala Sub Bagian Humas mengungkapkan saat ini perkerjaan yang dikerjakan relatif lebih fleksibel. Hal yang berbeda di unit kerja sebelumnya:

"Jangankan (untuk) mengobrol,
(bahkan, waktu untuk) makan kadang
lupa."

Keempat, Faktor Eksternal Organisasi. Kepala Biro Fasilitasi Kebijakan Energi dan Persidangan berpandangan dengan organisasi yang masih terkotakkotak, Ia menjelaskan bahwa cara untuk mengelola organisasi adalah dengan seni kepemimpinan:

"Sebagai pimpinan yang berat itu
mengatur ini (faktor eksternal:
keuangan). Anggaran APBN (Anggaran
pendapatan dan Belanja Negara)
seratus persen untuk kerja. Itu adalah
art(seni) dari situ (untukbisa mengelola
keuangan).

Kepala Bagian Fasilitasi Rencana Umum Energi menyikapi dengan turunnya alokasi anggaran dari tahun anggaran sebelumnya tidak menurunkan semangat pegawai dalam bekerja:

"Tupoksi (tugas, pokok dan fungsi)-nya ada. (Pada Bagian Humas dan Persidangan) fungsi kehumasan tetap jalan, (tetap) membuat berita. Ada sesuatu yang dihasilkan. PNS dibayar sesuai dengan tusi (tugas dan fungsi)nya."

Dengan adanya penurunan anggaran pada tahun anggaran 2019, Kepala Sub Bagian Keprotokolan mengungkapkan bahwa memiliki efek terhadap produktivitas kerja:

"Kita bekerja berbasis anggaran. Kinerja, anggaran dan output. Output jadi tidak banyak. Produktifitas (tetap) 
maksimal, tapi tidak banyak apa yang bisa kita hasilkan. Apapun yang kita kerjakan maksimal, tapi output tidak sebanyak dulu. Dengan output tidak banyak, pekerjaan tidak banyak, jadi kurang produktif. Produktivitas menurun."

Kepala Sub Bagian Penyediaan Energi mengungkapkan bahwa dengan penurunan anggaran dari tahun sebelumnya tetap bersama-sama dalam tim untuk bekerja dengan maksimal. Untuk itu lebih memilih untuk mempersuasi dan memotivasi anggota timnya untuk dapat berkerja secara masksimal:

"Lebih banyak persuasi dan motivasi. Memang keadaan seperti ini, (namun tetap) kita bersama-sama dalam satu tim (secara maksimal)."

Protokol menyebutkan bahwa kesejahteraan sangat diidamkan para pegawai. Bahkan, ia menjelaskan bahwa faktor ekonomi, dapat mempengaruhi pikiran pegawai:

"Intinya ada kesejahteraan. Manusia menjadi rampok, manusia menjadi maling, manusia menjadi pembunuh, itu faktor ekonomi, karena keuangan. Kesejahteraan bisa mempengaruhi pikiran."

Pada strategi Komunikasi di Biro Fasilitasi Kebijakan Energi dan Persidangan dapat dijelaskan, yaitu pertama, penetapan komunikator. Kepala Sub Bagian Keprotokolan menjelaskan pimpinan teratas (Kepala Biro Fasilitasi Kebijakan Energi dan Persidangan yang dapat menyatukan setiap pegawai di Biro Fasilitasi Kebijakan Energi dan Persidangan. Pengadministrasi data menyampaikan hal serupa bahwa leader (pimpinan) dapat mempersatukan seluruh pegawai, sehingga tidak terkotak-kotak lagi.

Sedangkan, Kepala Sub Bagian Humas menyampaikan bahwa Pejabat Administrator Kepala Bagian diperbolehkan untuk menyampaikan informasi, ini adalah fungsi Bagian Humas dan Persidangan. Pimpinan di sini, baik itu Kepala Biro
Fasilitasi Kebijakan Energi dan Persidangan, Kepala Bagian Humas dan Persidngan, Kepala Bagian Fasilitasi Kebijakan Energi dan Persidangan, Kepala Bagian Fasilitasi Rencana Umum Energi. Maupun Kepala Sub Bagian Dokumentasi, Kepala Sub Bagian Keprotkolan, Kepala Sub Bagian Humas, Kepala Sub Bagian Penyediaan Energi, Kepala Sub Bagian Pemanfaatan Energi, Kepala Sub Bagian Fasilitasi RUEN, dan Kepala Sub Bagian Pemantauan Pelaksanaan RUEN.

Kedua, Penetapan Target. Target yang ditetapkan adalah seluruh pegawai di lingkungan Biro Fasilitasi Kebijakan Energi Persidangan. Khususnya, pegawai yang memang dianggap belum memiliki kerja sama yang baik, walaupun hanya satu-dua pegawai saja.

Namun, Kepala Sub Bagian Humas menyampaikan:

"Seharusnya yang namanya kebijakan
seluruh masyarakat harus tahu. Maka
dari itu, setiap peraturan perundangan
(setelah) diundangkan setiap
masyarakat wajib mengetahui atau
dianggap mengetahui."

Ketiga, Menyusun Pesan. Kepala Sub Bagian Humas menyampaikan bahwa pesan yang disusun merupakan setidaknya keberadaan kebijakan dan dapat dipastikan ada hal-hal yang bersifat kewajiban dan larangan. Kebijakan yang disampaikan dapat berupa arahan Pimpinan, tindak lanjut hasil pembahasan rapat, sampai dengan peraturan perundangan yang sudah ditetapkan oleh Pemerintah.

Kepala Sub Bagian Keprotokolan menjelaskan jika sistem bisa dirubah, manajerial atau ketata-laksanaannya dirubah dapat membuat maksimal pelaksanaan tugas dan fungsi setiap Bagian di lingkungan Biro Fasilitasi Kebijakan Energi dan Presidangan. Namun, demikian dengan merubah manajerial memerlukan proses dan waktu yang bertahap dan tidak singkat. 
Keempat, pemilihan media dan saluran komunikasi. Kepala Sub Bagian Humas menyampaikan bahwa media yang digunakan adalah media elektronik dan online yang efektif. Protokol menjelaskan bahwa rapat dapat dijadikan sarana untuk berkomunikasi setiap Bagian untuk membahas tentang perencanaan energi seperti Outlook Energi Indonesia, dan Kajian tentang energi yang diikuti oleh ketiga Bagian.

Media komunikasi yang digunakan yaitu berupa media percakapan seperti aplikasi WhatsApp, baik itu jalur pribadi (japri) maupun grup percakapan Biro Fasilitasi Kebijakan Energi dan Persidangan. Media daring bisa melalu surat elektronik (email) baik itu melalui e-mail den.go.id, esdm.go.id maupun e-mail dari Google dan Yahoo.

Saluran komunikasi yang digunakan kelompok melalui rapat Biro yang menghadirkan seluruh pegawai di Biro Fasilitasi Kebijakan Energi dan Persidangaan. Rapat setiap Bagian yang dihadiri oleh seluruh pegawai di lingkungan Bagian Humas dan Persidangan, Bagian Fasilitasi Kebijakan Energi dan Bagian Fasilitasi Rencana Umum Energi. Saluran komunikasi antar pribadi yang digunakan seperti melakukan komunikasi antar pribadi, seperti e-mail, telepon, WhatsApp, Short Message Service (SMS). Walaupun, SMS sudah tidak lagi populer, seperti aplikasi WhatsApp, namun masih digunakan untuk saluran komunikasi.

Kelima, efek yang diharapkan. Kepala Sub Bagian Keprotokolan menyampaikan bahwa pada dasarnya setiap pegawai sama, menginginkan keguyuban dalam Biro Fasilitasi Kebijakan Energi dan Persidangan. Walaupun terkadang beberapa ego pegawai muncul, namun masing-masing pegawai mempunyai rasa saling memiliki.

Protokol menyampaikan bahwa dengan rapat bersama tersebut dapat membuat setiap pegawai ikut dan saling berfikir untuk menghasilkan outcome yang lebih baik. Sementara, Kepala Sub Bagian Humas menyampaikan bahwa masyarakat menjadi mengetahui kebijakan disampaikan, sehingga masyarakat mengetahui hak dan kewajiban.

Berdasarkan hasil wawancara yang dilakukan kepada Kepala Biro Fasilitasi Kebijakan Energi dan Persidangan, Kepala Bagian Fasilitasi Rencana Umum Energi, Kepala Sub Bagian Penyediaan Energi, Kepala Sub Bagian Dokumentasi, Kepala Sub Bagian Keprotokolan, Kepala Sub Bagian Humas, Pengadministrasi Data dan Protokol, serta observasi dan peninjauan literatur dalam penelitian yang telah dilakukan dalam menjawab iklim komunikasi organisasi dan strategi komunikasi di Biro Fasilitasi Kebijakan Energi dan Persidangan Setjen DEN, akan dijabarkan di bawah ini.

Penelitian ini pada dasarnya bertujuan untuk menemukan jawaban mengenai iklim komunikasi organisasi dan strategi komunikasi di Biro Fasilitasi Kebijakan Energi dan Persidangan Setjen DEN. Berdasarkan analisa iklim komunikasi organisasi di Biro Fasilitasi Kebijakan Energi dan Persidangan sudah berjalan, walaupun strategi komunikasi Biro Fasilitasi Kebijakan Energi dan Persidangan belum dijalankan dengan konsisten

Penelitian terdahulu Harivarman, (2016: 513) menjelaskan adanya perbedaan persepsi antara pimpinan dan bawahan terhadap pelaksanaan kegiatan dan program, terbatasnya praktik sharing informasi dari pihak manajemen kepada pegawai pelaksana dan pengaruh gaya kepemimpinan atasan dalam pelaksanaan kegiatan dalam organisasi. Perbedaan persepsi pada Biro Fasilitasi Kebijakan Energi dan Persidangan tidak terlihat pada pelaksanaan tugas dan fungsi, namun lebih kepada beberapa individu yang belum dapat bekerja sama dalam tim secara maksimal, namun keterbatasan sharing informasi dari pimpinan kepada pegawai di bawahnya yang memang belum berjalan secara teratur. Adapun gaya kepemimpinan sudah dirasakan baik, agar iklim komunikasi organisasi dapat menjadi guyub. Sehingga, 
pelaksanaan tujuan organisasi yaitu tugas dan fungsi dapat berjalan dengan maksimal.

Penelitian Hambali; dkk, (2018: 107) menjelaskan alur komunikasi secara formal dalam organisasi tertata secara teratur dan mengikuti prosedur yang telah berlaku. Pola komunikasi yang dalam penyebaran informasi juga terjalin secara langsung dengan adanya feedback dari setiap penerima pesan. Selain itu, dari pola komunikasi yang terbentuk akan membuat hubungan interaksi antar anggota akan tetap harmonis karena penyebaran informasi terjadi secara transparan dan tidak kaku. Alur komunikasi pada Biro Fasilitasi Kebijakan Energi dan Persidangan belum tertata secara teratur, tergantung adanya disposisi atau arahan pimpinan, sehingga perlu pengaturan lebih lanjut untuk pelaksanaan tugas dan fungsi secara maksimal, seperti pola rapat pekanan atau bulanan yang mengatur rencana dan evaluasi kegiatan.

Pola komunikasi dalam penyebaran informasi masih terbatas pada informasi yang disampaikan dalam aplikasi WhatsApp dan aplikasi internal Nadine, walaupun lebih sering menggunakan aplikasi WhatsApp karena realtime dan lebih cepat. Selain itu, dari pola komunikasi yang sudah terbentuk saat ini, Biro Fasilitasi Kebijakan Energi dan Persidangan masih terkotak-kotak, sehingga memerlukan pola komunikasi yang "mencairkan" ketegangan (kotak-kotak) antar Bagian, sehingga ada perasaan saling memiliki dan guyub, dengan pertemuan yang lebih rutin dan sesekali mengadakan acara luar kantor seperti outbond serta pemberian reward and punishment dijalankan dengan tertib sesuai pegawai yang berprestasi dan pegawai yang indisipliner.

Penelitian Purnomo (2018: 24)
mengungkapkan bahwa pelaksanaan
kebijakan komunikasi organisasi pada
Pemerintahan di Indonesia tidak terlepas dari
faktor-faktor yang menunjang dan
menghambat. Faktor tersebut adalah faktor
pimpinan, tingkah laku pegawai, kelompok
kerja, dan eksternal organisasi. Pada Biro

Fasilitasi Kebijakan Energi dan Persidangan faktor yang menunjang adalah faktor pimpinan dengan berusaha memberikan trigger untuk output pada organisasi dan memotivasi pegawai di bawahnya untuk memiliki dedikasi sebagai ASN.

Sedangkan pada faktor yang menghambat yaitu Faktor tingkah laku pegawai ada beberapa pegawai saja yang cara berkomunikasinya tidak secara dua arah, sehingga mendominasi dan memerlukan koordinasi dengan pimpinan dan pegawai lainnya. Untuk faktor (tingkah laku) kelompok kerja perlu mendorong motivasi antar pegawai diperlukan pemberian reward, dan faktor eksternal organisasi bahwa dengan menurunnya anggaran dari tahun sebelumnya, tetap bekerja secara maksimal walaupun memiliki efek terhadap produktivitas kerja.

Penelitian (Ramadani, 2019a: 11) menjelaskan bahwa keterbatasan anggaran tidak mempengaruhi motivasi bekerja dan bahkan menjadi masukkan untuk lebih meningkatkan lagi dalam hal sinergi pengelolaan komunikasi publik ke depan. Keterbatasan anggaran pada Biro Fasilitasi kebijakan Energi dan Persidangan disikapi dengan bijak oleh pegawai, dengan pimpinan terus memberikan persuasi dan motivasi kepada pegawai agar tetap dapat bekerja secara maksimal. Selain itu, pimpinan mengingatkan dengan dedikasi sebagai ASN, sehingga semangat bekerja pegawai tetap ada untuk melaksanakan tugas dan fungsi organisasi dengan maksimal.

Penelitian yang dilakukan Pricahyadi \& Ramadani (2019: 112) menemukan bahwa strategi komunikasi sudah dilakukan, namun belum dijalankan dengan perencanaan yang sistematis. Begitu halnya dengan Biro Fasilitasi Kebijakan Energi dan Persidangan, strategi komunikasi sudah dilakukan, namun belum dijalankan dengan perencanaan yang sistematis. Sehingga efek yang diharapkan dalam strategi komunikasi yaitu keguyuban bekerjasama dalam tim agar pelaksanaan tugas dan fungsi dapat menghasilkan outcome yang lebih baik. 


\section{PENUTUP}

Iklim komunikasi organisasi pada Biro Fasilitasi Kebijakan Energi dan Persidangan Setjen DEN diungkap bahwa pada faktor pimpinan, pimpinan memberikan motivasi kepada bawahan dan dengan dedikasi sebagai ASN untuk menjalankan pekerjaan dengan baik. Pada faktor tingkah laku pegawai, masih terkotak-kotak antar generasi, antar Bagian, dan beberapa orang yang mendominasi belum berkomunikasi secara dua arah dengan baik. Pada tingkah laku kelompok kerja juga masih terkotak-kotak antar Bagian di lingkungan Biro Fasilitasi Kebijakan Energi dan Persidangan. Sedangkan, pada faktor eksternal organisasi, penurunan anggaran memiliki efek terhadap produktivitas kerja yang dihasilkan.

Pada strategi komunikasi, komunikator adalah pimpinan yang dapat mempersatukan seluruh pegawai, sehingga tidak terkotakkotak lagi. Target yang ditetapkan adalah seluruh pegawai di lingkungan Biro Fasilitasi Kebijakan Energi Persidangan. Pesan yang disusun berisikan mengenai kebijakan, yang dapat berupa arahan pimpinan, tindak lanjut hasil pembahasan rapat, sampai dengan peraturan perundang-undangan. Media yang digunakan aplikasi WhatsApp dan e-mail. Saluran komunikasi yang digunakan kelompok melalui rapat Biro, rapat Bagian, antar pribadi seperti e-mail, telepon, WhatsApp, dan SMS. Sedangkan efek yang diharapkan adalah keguyuban dalam Biro Fasilitasi Kebijakan Energi dan Persidangan.

Rekomendasi kebijakan yang dapat diterapkan ke depan adalah dengan melakukan rapat secara rutin terkait perencanaan dan evaluasi kegiatan, baik itu dalam lingkup Bagian maupun Biro, dan perlunya mencairkan kotak-kotak antar bagian dan pegawai serta pemberian reward bagi pegawai berprestasi dan punishment bagi pegawai yang indisipliner, sehingga pelaksanaan tugas dan fungsi organisasi dapat berjalan maksimal. Untuk penelitian ke depan, disarankan mendalami efektifitas komunikasi organisasi.

\section{DAFTAR PUSTAKA}

Atmaja, S., \& Dewi, R. (2018). Komunikasi Organisasi (Suatu tinjauan Teoritis dan Praktis). Inter Komunika Jurnal Komunikasi, 3(2), 192-206.

Badrudin, S., Muslimin, \& Pratama, H. O. (2017). Analisis Komunikasi Organisasi di Pusat Informasi Haji Kantor Wilayah Kementerian Agama Provinsi Sumatera Selatan. JKPI: Jurnal Komunikasi Islam Dan Kehumasan, 1(2), 81-101.

Cangara, H. (2018). Perencanaan dan Strategi Komunikasi. Jakarta: Rajagrafindo Perkasa.

Erliana, H. (2005). Komunikasi Pemerintahan. Bandung: Refika Aditama.

Hambali, Muhaimin, A., \& Rahmadini, M. (2018). Pola Komunikasi organisasi Dalam Pengembangan program Studi Ilmu Komunikasi Fakultas Ilmu Sosial dan Ilmu Politik Universitas Islam Negeri Raden Fatah Palembang. Jurnal Studi Sosial Dan Politik, 2(2), 96-108.

Harivarman, D. (2016). Hambatan Komunikasi Internal di Organisasi. Jurnal ASPIKOM, 3(3), 508-519.

Hasyim, N. M. (2016). Komunikasi Organisasi di Perguruan Tinggi Islam Negeri (Studi Kasus di Fakultas Dakwah dan Komunikasi UIN Sunan kalijaga). Jurnal Promedia, II(2), 1-36.

Jumrad, O. T., \& Sari, I. D. M. (2019). Fungsi Komunikasi dalam Organisasi Melalui Group Chat Whatsup Oriflame Jurnal Common, 3(1), 104-114.

Khalid, I., \& Mukhtar, A. (2016). Energy Crisis: An Issue of Good Governance, A Way Forward. Journal of Political Studies, 23(1), 101-116.

Pricahyadi, M., \& Ramadani, T. (2019). Strategi Komunikasi Kebijakan 
pemerintah Provinsi DKI Jakarta Pada Peraturan Gubernur Nomor 110 Tahun 2018. Jurnal Ilmu Administrasi ( JIA ), XVI(1), 112-126.

Purnomo, A. (2018). Pelaksanaan kebijakan Komunikasi Organisasi Pemerintahan di Indonesia. Jurnal Noken, 3(2), 11-26.

Ramadani, T. (2019a). Implementasi Kebijakan Pengelolaan Komunikasi Publik di Kementerian Energi dan Sumber Daya Mineral. Jurnal Borneo Administrator, 15(1), 1-18.

Ramadani, T. (2019b). Pengelolaan Komunikasi Publik. Jurnal Good Governance, 15(1), 11-27.

Rodiah, S., \& Yusup, P. M. (2018). Strategi Komunikasi dalam Pengembangan Desa Agro Wisata di Kabupaten Pangandaran. Jurnal Signal Unswagati Cirebon, 6(2), $1-13$.

Rosfiantika, E., \& Rodiah, S. (2015). Communication Strategies of Natural Resources and Environment Protection and Management Policies Based on Local Wisdom in Tasikmalaya Regency. Edutech, 1(2), 273-290.
Santoso, A. (2015). Iklim Komunikasi Organisasi di Hotel Savana Malang. Jurnal E-Komunikasi, 3(2), 1-8.

Santoso, R. (2017). Kebijakan Energi di Indonesia: Menuju Kemandirian. Jurnal Analis Kebijakan, 1(1), 28-36.

Sedarmayanti. (2018). Komunikasi Pemerintahan. Bandung: Refika Aditama.

Sugiarto, A., Priyowidodo, G., \& Indrayani, I. I. (2018). Iklim komunikasi organisasi di PT . Starindo Anugerah Abadi Surabaya Pendahuluan. Jurnal E-Komunikasi, 6(2), 1-9.

Suparna, P., R, T. S., \& Winoto, Y. (2013). Keterbukaan Komunikasi dalam Menciptakan Iklim Komunikasi yang Kondusif di Perpustakaan. Jurnal Kajian Informasi Dan Perpustakaan, 1(2), 157164.

Wijaya, I. S. (2013). Komunikasi Interpersonal dan Iklim Komunikasi dalam Organisasi. Jurnal Dakwah Tabligh, 14(1), 115-126. 